\title{
Antileishmanial, antitrypanosomal, and cytotoxic screening of ethnopharmacologically selected Peruvian plants
}

\author{
Azucena González-Coloma • Matías Reina • \\ Claudia Sáenz • Rodney Lacret • Lastenia Ruiz-Mesia • \\ Vicente J. Arán • Jesús Sanz • Rafael A. Martínez-Díaz
}

Received: 28 June 2011 / Accepted: 2 September 2011 /Published online: 16 September 2011

(C) Springer-Verlag 2011

\begin{abstract}
Extracts (34) from eight plant species of the Peruvian Amazonia currently used in traditional Peruvian medicine, mostly as antileishmanial remedies and also as painkiller, antiseptic, antipyretic, anti-inflamatory, antiflu, astringent, diuretic, antipoison, anticancerous, antiparasitic, insecticidal, or healing agents, have been tested for their antileishmanial, antitrypanosomal, and cytotoxic activity. Plant species were selected based on interviews conducted with residents of rural areas. The different plant parts were dried, powdered, and extracted by maceration with different solvents (hexane, chloroform, and 70\% ethanol-water). These extracts were tested on promastigote forms of Leishmania infantum strain PB75, epimastigote forms of Trypanosoma cruzi strain $\mathrm{Y}$, and the mammalian $\mathrm{CHO}$ cell
\end{abstract}

A. González-Coloma • C. Sáenz

Instituto de Ciencias Agrarias,

Consejo Superior de Investigaciones Científicas,

C/Serrano 115-bis,

28006 Madrid, Spain

\section{Reina}

Instituto de Productos Naturales y Agrobiología,

Consejo Superior de Investigaciones Científicas,

Avda. Astrofísico Francisco Sánchez 3,

38206 La Laguna, Tenerife, Spain

\section{R. Lacret}

Grupo de Alelopatía, Departamento de Química Orgánica,

Facultad de Ciencias, Universidad de Cádiz,

Avda. República Saharaui S/N,

11510 Cadiz, Spain

\section{Ruiz-Mesia}

Laboratorio de Productos Naturales Antiparasitarios de la

Amazonía Peruana,

Universidad Nacional de la Amazonía Peruana,

Pasaje Los Paujiles S/N Nuevo San Lorenzo,

San Juan Bautista, Maynas, Peru line. Parasite viability and nonspecific cytotoxicity were analyzed by a modified MTT colorimetric assay method. The isolation and identification of pure compounds from selected extracts were performed by column chromatography, gas chromatography mass spectrometry (GC-MS; mixtures), spectroscopic techniques [MS, infrared (IR), ultraviolet (UV)], and mono and two-dimensional ${ }^{1} \mathrm{H}$ and ${ }^{13} \mathrm{C}$ nuclear magnetic resonance (NMR; COSY, HSQC, NOESY) experiments. Chondodendron tomentosum bark and Cedrela odorata were the most active extracts against Leishmania, while C. odorata and Aristoloquia pilosa were the most active against Trypanosoma, followed by Tabebuia serratifolia, Tradescantia zebrina, and Zamia ulei. Six compounds and two mixtures were isolated from $Z$. ulei

V. J. Arán

Instituto de Química Médica,

Consejo Superior de Investigaciones Científicas,

C/Juan de la Cierva 3,

28006 Madrid, Spain

\section{J. Sanz}

Instituto de Química Orgánica General,

Consejo Superior de Investigaciones Científicas,

C/Juan de la Cierva 3,

28006 Madrid, Spain

\section{R. A. Martínez-Díaz ( $\square)$}

Departamento de Medicina Preventiva,

Salud Pública y Microbiología, Facultad de Medicina,

Universidad Autónoma de Madrid,

C/Arzobispo Morcillo S/N,

28029 Madrid, Spain

e-mail: rafael.martinez@uam.es 
[cycasin (1)], T. serratifolia \{mixtures 1-2, and naphthoquinones 2-acetyl-4H,9H-naphtho[2,3-b]furan-4,9-dione (2) and 2-(1-hydroxyethyl)-4H,9H-naphtho[2,3-b]furan4,9-dione (3) $\}$, and C. tomentosum [chondrocurine (4); $(S$, $S^{\prime}$ )-12-O-methyl(+)-curine (5); and cycleanine (6)]. Four compounds and the two mixtures exhibited significant activity.

\section{Introduction}

The Peruvian Amazonia is among the regions of the planet with the greatest plant diversity. Many of these plants are traditionally used in popular medicine (Kvist et al. 2006; Mejia and Rengifo 2000; Perez and Iannacone 2006; Rojas et al. 2003).

Phytotherapy has recently received considerable attention as an alternative to chemotherapy in parasitic disease control. Trypanosoma cruzi is the aethiologic agent of Chagas disease, a public health problem in many Latin American countries. Additionally, the population emigration from South American countries to Europe has resulted in the presence of Chagas disease in some European countries (Gascon et al. 2010; Muñoz et al. 2007). The current treatment of Chagas disease is a challenge since the only available drugs, nifurtimox and benznidazole, have severe side effects, and problems are encountered in their production and distribution (Muelas Serrano et al. 2000; Sra et al. 2004).

Leishmaniasis is a protozoan parasitic disease endemic in 88 countries with a high associated morbidity and mortality rate. The drugs most commonly used to treat leishmaniasis are pentavalent antimonials, amphotericin B, paromomycin, and pentamidine, which require high dosage over long periods and are administered parenterally. In the case of amphotericin $\mathrm{B}$, toxicity and high cost are other limitations (Passero et al. 2011). These drugs are far from satisfactory due to their side effects at effective doses. Even miltefosine, the newly introduced drug, has indicated potential resistance against visceral leishmaniasis (Sánchez-Cañete et al. 2009).

In both cases, Chagas disease and leishmaniasis, the search for new compounds to improve current treatments is urgently needed (Correa et al. 2011; Croft et al. 2005; Ghosh et al. 2011; Murray et al. 2005).

In this work, we have screened the in vitro activity of 34 extracts obtained from eight plant species from the Peruvian rain forest against Leishmania infantum promastigotes and T. cruzi epimastigotes as a first step in the search of new natural active compounds. The cytotoxic effects on mammalian cells (CHO cell line) were tested in all cases. All the plants studied are traditionally used in popular medicine, some of them as leishmanicidal and antiparasitic agents
(Estevez et al. 2007; Kvist et al. 2006; Mackinnon et al. 1997; Mejia and Rengifo 2000; Perez and Iannacone 2006; Rojas et al. 2003). Furthermore, the active compounds from Chondodendron tomentosum, Tabebuia serratifolia, and Zamia ulei have been isolated and characterized.

\section{Material and methods}

General experimental procedures

Gas chromatography mass spectrometry (GC-MS) analysis was performed using a Hewlett-Packard HP 5890A gas chromatograph coupled to a Hewlett-Packard HP 5971A mass detector in the electron impact mode $(70 \mathrm{eV})$ and equipped with a capillary column. High performance liquid chromatography (HPLC) was carried out in a Gilson apparatus with ultraviolet (UV) detector and SP-4270 integrator. Optical rotations were determined at room temperature using a Perkin-Elmer 241 polarimeter. Nuclear magnetic resonance (NMR) spectra were measured on a Bruker AMX-500 spectrometer with pulsed field gradient, using the solvent as an internal standard $\left(\mathrm{CDCl}_{3}\right.$, at $\delta_{\mathrm{H}} 7.26$ and $\left.\delta_{\mathrm{C}} 77.0\right)$. Mass spectra and high resolution MS (HRMS) were taken at $70 \mathrm{eV}$ in a Micromass Autospec and electrospray ionization MS (ESI-MS) were recorded in a LCT Premier XE Micromass spectrometer. Silica gel from Merck (15111 and 5554) was used for column chromatography and preparative thin-layer chromatography (TLC). Silica gel G 1500/LS 254 (200× $200 \times 0.25 \mathrm{~mm}$ plates), Schleicher \& Schuell, Ref. 391132 plates were used for semipreparative TLC.

\section{Plant material}

The different plant species were selected according to previous reports (Mejia and Rengifo 2000; Rojas et al. 2003) along with the information obtained from interviews conducted with people living in rural areas outside of the City of Iquitos (Table 1).

All plants were collected between July and August 2003 at the biological station Allpahuayo Mishana (Iquitos-Nauta Road, San Juan Bautista District, Province of Maynas, Department of Loreto), except for C. tomentosum, which was collected at the Regional Research Centre CRI-IIAPPucallpa also in July 2003. Harvested plants were identified and classified in the Herbarium Amazonense of the Universidad Nacional de la Amazonía Peruana, where voucher samples are on deposit.

Preparation of extracts

The different plant parts were dried, powdered, and extracted by maceration with different solvents (hexane, 
Table 1 Plants selected for in vitro investigation and parts of plants studied

\begin{tabular}{|c|c|c|c|c|c|c|}
\hline $\begin{array}{l}\text { Botanical name } \\
\text { and family }\end{array}$ & $\begin{array}{l}\text { Voucher } \\
\text { number }\end{array}$ & $\begin{array}{l}\text { Common } \\
\text { name }\end{array}$ & Plant part & Extract & $\begin{array}{l}\text { Yield } \\
(\%)\end{array}$ & Traditional applications \\
\hline \multicolumn{7}{|l|}{$\begin{array}{l}\text { Aristolochia } \\
\text { pilosa L. }\end{array}$} \\
\hline \multirow[t]{5}{*}{ Aristolochiaceae } & \multirow[t]{5}{*}{025860} & \multirow[t]{5}{*}{ Huancahui sacha } & \multirow[t]{2}{*}{ Stem } & $\begin{array}{l}\mathrm{H} \\
\mathrm{C}\end{array}$ & $\begin{array}{l}0.18 \\
0.43\end{array}$ & \multirow[t]{5}{*}{ Snake bite } \\
\hline & & & & E-w & 0.70 & \\
\hline & & & \multirow[t]{3}{*}{ Leaf } & $\mathrm{H}$ & 0.33 & \\
\hline & & & & $\mathrm{C}$ & 0.85 & \\
\hline & & & & E-w & 1.00 & \\
\hline \multicolumn{7}{|l|}{$\begin{array}{l}\text { Brunfelsia } \\
\text { grandiflora } \mathrm{L} .\end{array}$} \\
\hline \multirow[t]{5}{*}{ Solanaceae } & \multirow[t]{5}{*}{026365} & \multirow[t]{5}{*}{ Chiric sanango } & \multirow[t]{2}{*}{ Stem } & $\begin{array}{l}\mathrm{H} \\
\mathrm{C}\end{array}$ & $\begin{array}{l}0.19 \\
0.39\end{array}$ & \multirow{5}{*}{$\begin{array}{l}\text { Leishmaniasis, reconstituent, } \\
\text { antirheumatic febrifuge, yellow } \\
\text { fever, antisyphilitic, diuretic }\end{array}$} \\
\hline & & & & E-w & 1.70 & \\
\hline & & & \multirow[t]{3}{*}{ Leaf } & $\mathrm{H}$ & 0.15 & \\
\hline & & & & $\mathrm{C}$ & 0.46 & \\
\hline & & & & E-w & 1.22 & \\
\hline \multicolumn{7}{|c|}{ Cedrela odorata L. } \\
\hline \multirow[t]{3}{*}{ Meliaceae } & \multirow[t]{3}{*}{033574} & \multirow[t]{3}{*}{ Cedro amargo } & \multirow[t]{3}{*}{ Bark } & $\mathrm{H}$ & 0.37 & \multirow[t]{3}{*}{ Astringent, febrifuge, tonic } \\
\hline & & & & $\mathrm{C}$ & 0.92 & \\
\hline & & & & E-w & 2.43 & \\
\hline \multicolumn{7}{|l|}{$\begin{array}{l}\text { Chondodendron } \\
\text { tomentosum } \\
\text { Ruiz \& Pavón }\end{array}$} \\
\hline \multirow[t]{7}{*}{ Menispermaceae } & \multirow[t]{7}{*}{033896} & \multirow[t]{7}{*}{ Curare } & \multirow[t]{3}{*}{ Bark } & $\mathrm{H}$ & 0.53 & Antiseptic, anti-inflamatory, rheumatism, \\
\hline & & & & $\mathrm{C}$ & - & jaundice, dropsy, gonorrhoea, anaesthetic \\
\hline & & & & E-w & 1.42 & \\
\hline & & & Leaf & $\mathrm{H}$ & 0.90 & \\
\hline & & & & $\mathrm{C}$ & - & \\
\hline & & & & E-w & 3.73 & \\
\hline & & & Bark \& leaf & A & 0.26 & \\
\hline $\begin{array}{l}\text { Paullinia clavige } \\
\text { Schltdl }\end{array}$ & & & & & & \\
\hline Sapindaceae & 033368 & Sacha yoko & Bark & $\mathrm{H}$ & 0.16 & Insecticide \\
\hline & & & & $\mathrm{C}$ & 0.75 & \\
\hline & & & & E-w & - & \\
\hline $\begin{array}{l}\text { Tabebuia } \\
\text { serratifolia }(\mathrm{Ba} \\
\text { G. Nicholson }\end{array}$ & & & & & & \\
\hline Bignoniaceae & 034665 & Tahuarí & Bark & $\mathrm{H}$ & 0.49 & Bronchitis, flu, gallstones, anticancerous, \\
\hline & & & & $\mathrm{C}$ & 1.16 & diabetes, fever, leishmaniasis, rheumatism \\
\hline & & & & E-w & 1.45 & \\
\hline $\begin{array}{r}\text { Tradescantia zeb } \\
\text { (Rose) D.R. Hu }\end{array}$ & & & & & & \\
\hline Commeliaceae & 011382 & Oreja de tigre & Aerial part & $\mathrm{H}$ & 1.36 & Insecticidal \\
\hline & & & & $\mathrm{C}$ & 2.27 & \\
\hline & & & & E-w & 2.57 & \\
\hline Zamia ulei Damı & & & & & & \\
\hline Zamiaceae & 027675 & Lengua de perro & Underground & $\mathrm{H}$ & - & Leishmaniasis, healing \\
\hline & & & tuberous stem & $\mathrm{C}$ & - & \\
\hline & & & & E-w & 2.24 & \\
\hline
\end{tabular}

$H$ Hexane, $C$ chloroform, $E-w$ Hydroalcoholic extract, $A$ alkaloid extract 
chloroform, and $70 \%$ ethanol-water) for $48-72 \mathrm{~h}$ at room temperature. The extracts were filtered and concentrated in vacuo (Table 1). A mixture of $\mathrm{CH}_{2} \mathrm{Cl}_{2}$ and $0.5 \mathrm{M} \mathrm{H}_{2} \mathrm{SO}_{4}$ $(1: 1)$ was added to the ethanolic extract and stirred for $12 \mathrm{~h}$ to prepare the alkaloidal extract from $C$. tomentosum. The aqueous phase was filtered, its $\mathrm{pH}$ increased to 9 with $\mathrm{NH}_{4} \mathrm{OH}$ and repeatedly extracted with $\mathrm{CH}_{2} \mathrm{Cl}_{2}$. The evaporation of the solvent gave a crude alkaloidal extract.

Fractionation and isolation of pure compounds

The dry ground rhizome of Z. ulei $(300 \mathrm{~g})$ was extracted by maceration with ethanol for $48-72 \mathrm{~h}$ at room temperature to give $23.1 \mathrm{~g}$ of extract $(7.7 \%$ yield). The extract was chromatographed on a vacuum liquid chromatograph (VLC) column and eluted with an n-Hex: EtOAc gradient of increasing polarity to give seven fractions. Further purification of the active fractions 6 and 7 by $\mathrm{CC}$ and/or HPLC ( $\lambda 250 \mathrm{~nm}$; flow rate $3 \mathrm{ml} / \mathrm{min}$, Ultrasphere $\mathrm{Si}$ column $10 \times 250 \mathrm{~mm}, 5 \mu \mathrm{m}$ particle size) eluted with mixtures of n-Hex:EtOAct of increasing polarity resulted in the isolation of cycasin (1) $\left(40.6 \mathrm{mg}, 13.5 \times 10^{-3} \%\right)$.

Cycasin (1) ESI-MS: $m / z 275.0855[\mathrm{M}+\mathrm{Na}]^{+}$; calculated for $\mathrm{C}_{8} \mathrm{H}_{16} \mathrm{~N}_{2} \mathrm{O}_{7} \mathrm{Na}$; ${ }^{1} \mathrm{H}$ RMN (500 MHz, $\mathrm{CDCl}_{3}$ ): $\delta_{\mathrm{H}} 4.06$ $\left(3 \mathrm{H}\right.$, br t $\left., J=1.5 \mathrm{~Hz},=\mathrm{NO}-\mathrm{CH}_{3}\right), 5.05$ and $5.15(1 \mathrm{H}$ each, $\mathrm{dq}, J=14.4$ and $\left.1.6 \mathrm{~Hz}, \mathrm{O}-\mathrm{CH}_{2}-\mathrm{N}\right), 4.52(1 \mathrm{H}, \mathrm{d}, J=$ $12.8 \mathrm{~Hz}, \mathrm{H}-1$, anomeric proton), 3.84 and $3.64(1 \mathrm{H}$, each, $\mathrm{dd}, J=2.2,12.0$ and $J=5.5,12.0 \mathrm{~Hz}$, respectively, $\mathrm{C}_{2} \mathrm{OH}$ ), 3.20 and $3.40(4 \mathrm{H}, \mathrm{m}$ geminal to the hydroxyl proton of the glycoside). ${ }^{13} \mathrm{C}$ RMN $\left(500 \mathrm{MHz}, \mathrm{CDCl}_{3}\right): \delta_{\mathrm{C}} 55.6$ (q, NO$\left.\mathrm{CH}_{3}\right), 81.2$ (t, C-7), 101.1 (d, C-1), 61.2 (t, C-6), 76.7 (d, C2), 76.5 (d, C-3), 73.5 (d, C-4), 70.1 (d, C-5).

T. serratifolia bark $(650 \mathrm{~g})$ was extracted by maceration with ethanol for $48-72 \mathrm{~h}$ at room temperature to give $53.6 \mathrm{~g}$ of extract (8.25\%). This extract was fractionated on a VLC column eluted with an AcOEt:MeOH gradient of increasing polarity to give ten fractions. Further purification of the active fractions 4,6 , and 10 by HLPC $(\lambda 250 \mathrm{~nm}$; flow rate $3 \mathrm{ml} / \mathrm{min}$, Ultrasphere Si column $10 \times 250 \mathrm{~mm}, 5 \mu \mathrm{m}$ particle size) eluted with mixtures of n-Hex:EtOAct of increasing polarity to give two compounds [2-acetylnaphtho[2,3-b] furan-4,9-dione (2) $\left(2.5 \mathrm{mg}, 3.8 \times 10^{-4} \%\right)$, 2-(1-hydroxyethyl)-naphtho[2,3-b]furan-4,9-dione (3) $(7.9 \mathrm{mg}, 1.22 \times$ $\left.10^{-3} \%\right)$ ] and two mixtures [mixture $1(26.2 \mathrm{mg}, 4.03 \times$ $\left.10^{-3} \%\right)$ and mixture $\left.2\left(5.9 \mathrm{mg}, 0.9 \times 10^{-3} \%\right)\right]$.

2-Acetyl-4H,9H-naphtho[2,3-b]furan-4,9-dione (2) EIMS: $\mathrm{m} / \mathrm{z}$ (rel. int.,\%): [M] $]^{+} 240$ (62), 225 (100), 197 (2). 173 (2). 157 (8), 141 (3), 129 (4), 113 (12), $76(6)$ y 57 (12). ${ }^{1} \mathrm{H}$ NMR $\left(500 \mathrm{MH}_{\mathrm{Z}}, \mathrm{CDCl}_{3}\right): \delta_{\mathrm{H}} 2.60(3 \mathrm{H}, \mathrm{s}, \mathrm{H}-11), 7.5(1 \mathrm{H}, \mathrm{s}$, H-3), 7.75 (2H, m, H-6 y H-7), 8.18 (2H, m, H-5 y H-8). ${ }^{13} \mathrm{C}$ NMR (400 $\left.\mathrm{MH}_{\mathrm{Z}}, \mathrm{CDCl}_{3}\right): \delta_{\mathrm{C}} 187.9(\mathrm{~s}, \mathrm{C}-10), 180.2$ (s, C-4),
174.4 (s, C-9), 155.8 (s, C-9a), 153.2 (s, C-3a), 137.4 (s, C2), 134.8 (d, C-6 and C-7), 134.7 (s, C-8a), 131.1 (s, C-4a), 127.6 (d, C-5 and C-8), 112.8 (d, C-3), 27.0 (q, C-11).

2-(1-Hydroxyethyl)-4H,9H-naphtho[2,3-b]furan-4,9-dione (3) EIMS: $m / z$ (rel. int.,\%): [M] 242 (44), 227 (100), 200 (48), 199 (39), 171 (20), 115 (24), 113 (7), 105 (24), 104 (11). HREIMS: $m / z 242.0575[\mathrm{M}]^{+}$; calculated for $\mathrm{C}_{14} \mathrm{H}_{10}$ $\mathrm{O}_{4} ;{ }^{1} \mathrm{H}$ NMR $\left(500 \mathrm{MHz}, \mathrm{CDCl}_{3}\right): \delta_{\mathrm{H}} 1.61(3 \mathrm{H}, \mathrm{d}, J=$ $6.7 \mathrm{~Hz}, \mathrm{H}-11), 5.03(1 \mathrm{H}, \mathrm{q}, J=6.7 \mathrm{~Hz}, \mathrm{H}-10), 6.84(1 \mathrm{H}, \mathrm{s}$, $\mathrm{H}-3), 7.74(2 \mathrm{H}, \mathrm{m}$, aromatic protons $), 8.19(2 \mathrm{H}, \mathrm{m}$, aromatic protons). ${ }^{13} \mathrm{C}$ NMR $\left(400 \mathrm{MH}_{\mathrm{Z}}, \mathrm{CDCl}_{3}\right): \delta_{\mathrm{C}}$ 180.7 (s, C-4), 173.5 (s, C-9), 165.1 (s, C-2), 151.9 (s, C9a), 151.0 (s, C-3a), 133.9 (d, C-6), 133.8 (d, C-7), 133.0 (s, C-8a), 132.5 (s, C-4a), 127.0 (d, C-5), 126.9 (d, C-8), 103.7 (d, C-3), 63.8 (d, C-10), 21.7 (q, C-11).

Mixtures 1-2 were analyzed by GC-MS. Working conditions were as follows: injector and transfer line temperature was $280^{\circ} \mathrm{C}$. A capillary column (HP-1, $30 \mathrm{~m} \times 0.25 \mathrm{~mm}$ i.d. $\times 0.25 \mu \mathrm{m}$ d.f.) was temperatureprogrammed from 70 to $270^{\circ} \mathrm{C}, 4^{\circ} \mathrm{C} \mathrm{min}^{-1}$. Electroninduced mass spectra (EIMS) and retention data were used to assess the identity of compounds by comparing them with those of standards or those found in the Wiley MS library. Quantitative data were obtained directly from the TIC peak areas.

The dry bark of $C$. tomentosum $(700 \mathrm{~g})$ was extracted by maceration with ethanol for $48-72 \mathrm{~h}$ at room temperature to give $54.6 \mathrm{~g}$ of extract $(7.8 \%$ yield). The extract was fractionated on a Sephadex column eluted in n-hex: $\mathrm{CH}_{2} \mathrm{Cl}_{2}: \mathrm{MeOH}$ 1:1:1, to give three fractions. The alkaloids from fraction 1 were extracted as described (Reina et al. $2001)$ to give a crude alkaloidal extract ( $1.8 \mathrm{~g}, 0.25 \%)$. This extract was purified by $\mathrm{CC}$ to give the alkaloids chondrocurine (4) (3.4 mg, $\left.4.8 \times 10^{-4} \%\right)$; 12-O-methyl-(+)-curine (5) $\left(15.4 \mathrm{mg}, 2.2 \times 10^{-3} \%\right)$, and cycleanine $(6)(5.3 \mathrm{mg}$, $\left.7.5 \times 10^{-4} \%\right)$.

Chondrocurine (4) $[\alpha]_{\mathrm{D}}=+130\left(\mathrm{c}, 6 \times 10^{-2}, \mathrm{CHCl}_{3}\right)$. EIMS: $\mathrm{m} / \mathrm{z}$ (rel. int.,\%): [M] 594 (28), 442 (10), 398 (7), 369 (4), 341 (2), 299 (22), 298 (100), 297 (23), 296 (17), 266 (7), 253 (15), 208 (23), 180 (23), 180 (43), 160 (23), 136 (33), 134 (18), 91 (14), 83 (10), 81 (12), 57 (50). HREIMS: $m / z$ $594.2733[\mathrm{M}]^{+}$; calculated for $\mathrm{C}_{36} \mathrm{H}_{38} \mathrm{~N}_{2} \mathrm{O}_{6} .{ }^{1} \mathrm{H}$ NMR $\left(500 \mathrm{MHz}, \mathrm{CDCl}_{3}\right): \delta_{\mathrm{H}} 6.57\left(1 \mathrm{H}, \mathrm{s}, \mathrm{H}-5^{\prime}\right), 5.87(1 \mathrm{H}, \mathrm{H}-$ $\left.8^{\prime}\right), 6.74(1 \mathrm{H}, \mathrm{s}, \mathrm{H}-5), 6.27\left(1 \mathrm{H}, \mathrm{d}, J=2.0 \mathrm{~Hz}, \mathrm{H}-10^{\prime}\right), 6.83$ $(1 \mathrm{H}, \mathrm{dd}, J=8.4,2.2 \mathrm{~Hz}, \mathrm{H}-14), 7.06(1 \mathrm{H}, \mathrm{dd}, J=8.4,2.2 \mathrm{~Hz}$, H-14'), $6.79\left(1 \mathrm{H}, \mathrm{dd}, J=8.0,2.0 \mathrm{~Hz}, \mathrm{H}-13^{\prime}\right), 6.70(1 \mathrm{H}, \mathrm{dd}$, $J=8.0,2.4 \mathrm{~Hz}, \mathrm{H}-13), 6.54(1 \mathrm{H}, \mathrm{dd}, J=8.0,2.0 \mathrm{~Hz}, \mathrm{H}-10)$, $3.92\left(1 \mathrm{H}, \mathrm{d}, J=8.5 \mathrm{~Hz}, \mathrm{H}-1^{\prime}\right), 3.83(3 \mathrm{H}, \mathrm{s}, \mathrm{OMe}), 3.78(3 \mathrm{H}$, s, OMe), $2.42(3 \mathrm{H}, \mathrm{s}, \mathrm{N}-\mathrm{Me}), 2.18(3 \mathrm{H}, \mathrm{s}, \mathrm{N}-\mathrm{Me}), 3.80(1 \mathrm{H}$, $\mathrm{m}, \mathrm{H}-1), 3.10$ and 3.30 (4H, m, H-3 y H-3'), 2.66 and 2.79 $\left(4 \mathrm{H}, \mathrm{m}, \mathrm{H}-4, \mathrm{H}-4^{\prime}\right) .{ }^{13} \mathrm{C}$ NMR (400 MHz, $\left.\mathrm{CDCl}_{3}\right): \delta_{\mathrm{C}} 155.4$ 
(s, C-12'), 148.0 (s, C-6'), 146.7 (s, C-6), 145.9 (s, C-12), 143.1 (s, C-11), 143.1 (s, C-7'), 137.9 (s, C-8), 137.2 (s, C7), 132.6 (s, C-9), 132.2 (d, C-10'), 131.7 (s, C-9'), 129.9 (d, C-14'), 128.6 (s, C-4a'), 128.1 (s, C-8a'), 125.7 (d, C14), 125.4 (s, C-8a), 124.6 (s, C-4a), 121.0 (d, C-10), 117.9 (d, C-8'), 115.4 (d, C-13), 114.9 (d, C-13'), 111.9 (d, C-5'), 107.7 (d, C-5), 64.4 (d, C-1'), 59.3 (d, C-1), 56.0 and 55.8 $(\mathrm{s}, 2 \times \mathrm{OMe}), 46.5\left(\mathrm{t}, \mathrm{C}-3^{\prime}\right), 44.2(\mathrm{t}, \mathrm{C}-3), 42.5$ and 42.4 (q, $2 \times \mathrm{N}-\mathrm{Me}), 25.2\left(\mathrm{t}, \mathrm{C}-4^{\prime}\right), 23.2$ (t, C-4).

$\left(S, S^{\prime}\right)$-12-O-methyl $(+)$-curine $(5)[\alpha]_{\mathrm{D}}=+128.7$ (c, 0.282, $\mathrm{CHCl}_{3}$ ). EIMS: $m / z$ (rel. int.,\%): [M] 608 (23), 607 (17), 593 (9), 313 (7), 312 (31), 31 (3), 298 (19), 297 (8), 296 (18), 190 (13), 86 (81), 84 (100). HREIMS: $\mathrm{m} / z$ 608.2884 $[\mathrm{M}]^{+}$; calculated for $\mathrm{C}_{37} \mathrm{H}_{40} \mathrm{O}_{6} \mathrm{~N}_{2} ;{ }^{1} \mathrm{H}$ NMR $(500 \mathrm{MHz}$, $\left.\mathrm{CDCl}_{3}\right) . \delta_{\mathrm{H}} 2.21(3 \mathrm{H}, \mathrm{s}, \mathrm{N}-\mathrm{Me}), 2.57$ (3H, s, N-Me), $2.43-$ $2.94\left(3 \mathrm{H}, \mathrm{m}, \mathrm{H}-4\right.$ and $\left.\mathrm{H}-4^{\prime}\right), 3.20(1 \mathrm{H}$, br d, J $=9.9 \mathrm{~Hz}, \mathrm{H}-$ $\alpha), 2.8\left(1 \mathrm{H}, \mathrm{m}, \mathrm{H}-\alpha^{\prime}\right), 3.36$ and 2.75 ( $1 \mathrm{H}$ each, $\mathrm{m}, \mathrm{H}-3$ and $\left.\mathrm{H}-3^{\prime}\right), 3.60(1 \mathrm{H}, \mathrm{m}, \mathrm{H}-1), 3.79$ and 2.88 (3H each, s, OMe), $3.92\left(1 \mathrm{H}, \mathrm{m}, \mathrm{H}-1^{\prime}\right), 3.95(3 \mathrm{H}, \mathrm{s}, \mathrm{OMe}), 5.82\left(1 \mathrm{H}, \mathrm{s}, \mathrm{H}-8^{\prime}\right)$, $6.26(1 \mathrm{H}, \mathrm{d}, J=2.0 \mathrm{~Hz}, \mathrm{H}-10), 6.51(1 \mathrm{H}, \mathrm{s}, \mathrm{H}-5), 6.60(1 \mathrm{H}$, br d, $\left.J=8.4 \mathrm{~Hz}, \mathrm{H}-14^{\prime}\right), 6.62\left(1 \mathrm{H}, \mathrm{s}, \mathrm{H}-5^{\prime}\right), 6.68(1 \mathrm{H}, \mathrm{d}, J=$ 8.4, $\left.2.4 \mathrm{~Hz}, \mathrm{H}-13^{\prime}\right), 6.75(1 \mathrm{H}, \mathrm{d}, J=8.0 \mathrm{~Hz}, \mathrm{H}-13), 6.78$ $(1 \mathrm{H}, \mathrm{br} \mathrm{dd}, J=8.5$ and $2.4 \mathrm{~Hz}, \mathrm{H}-11), 6.82(1 \mathrm{H}, \mathrm{br} \mathrm{d}, J=$ $8.1 \mathrm{~Hz}, \mathrm{H}-14), 7.05$ (1H, br d, $\left.J=8.4 \mathrm{~Hz}, \mathrm{H}-10^{\prime}\right) .{ }^{13} \mathrm{C} \mathrm{RMN}$ $\left(400 \mathrm{MHz}, \mathrm{CDCl}_{3}\right): \delta_{\mathrm{C}} 155.5\left(\mathrm{~s}, \mathrm{C}-12^{\prime}\right), 149.2$ (s, C-6'), 148.7 (s, C-7'), 146.7 (s, C-6), 145.4 (s, C-12), 144.1 (s, C11), 138.2 (s, C-8), 137.5 (s, C-7), 133.7 (s, C-9), 132.6 (s, C-9'), 132.5 (d, C-14'), 131.0 (d, C-10'), 128.8 (s, C-4'a), 128.4 (s, C-8'a), 125.7 (d, C-14), 125.3 (s, C-4a), 125.2 (s, C-8a), 120.1 (d, C-10), 117.9 (d, C-8'), 114.8 (d, C-11'), 114.2 (d, C-13'), 112.7 (d, C-13), 112.7 (d, C-5'), 108.3 (d, C-5), 64.9 (d, C-1), 58.7 (d, C-1'), 56.5 (q, OMe), 56.4 (q, $2 \times \mathrm{OMe}$ ), 48.5 and 44.7 (t each, $\mathrm{C}-3$ and $\mathrm{C}-3$ ', respectively), 42.8 and 43.4 (q each, N-Me), 38.2 and 39.7 (t each, C$\alpha$ and $\mathrm{C}-\alpha^{\prime}$, respectively), 26.7 (t, C-4'), 23.4 (t, C-4).

Cycleanine (6) EIMS: $[\mathrm{M}]^{+} \mathrm{m} / \mathrm{z}$ (rel. int.,\%) 622 (63\%), 313 (19), 312 (100), 311 (29), 204 (27), 190 (15), 174 (15), 159 (11), 146 (8), 145 (11). HREIMS: $m / z 622.3071[\mathrm{M}]^{+}$; calculated for $\mathrm{C}_{38} \mathrm{H}_{42} \mathrm{~N}_{2} \mathrm{O}_{6} \cdot{ }^{1} \mathrm{H}$ NMR: $\left(500 \mathrm{MHz}, \mathrm{CDCl}_{3}\right)$ $\delta_{\mathrm{H}} 2.53(\mathrm{~s}, 6 \mathrm{H}, 2 \times \mathrm{N}-\mathrm{Me}), 2.51(\mathrm{~m}, \mathrm{H}-\alpha), 3.25\left(\mathrm{~m}, \mathrm{H}-\alpha^{\prime}\right)$, 3.40 (s, 3H, OMe), 3.81 (s, 3H, OMe), $4.30(2 \mathrm{H}, \mathrm{d}, J=$ $10.3 \mathrm{~Hz}, \mathrm{H}-1$ and $\left.\mathrm{H}-1^{\prime}\right), 2.92$ and $3.29(2 \mathrm{H}, \mathrm{m}, \mathrm{H}-3$ and $\mathrm{H}-$ $\left.3^{\prime}\right), 3.01$ and $2.92(2 \mathrm{H}, \mathrm{m}, \mathrm{H}-4$ and H-4'), 6.57 (s, 2H, H-5 and $\left.\mathrm{H}-5^{\prime}\right), 7.82\left(\mathrm{dd}, 2 \mathrm{H}, J=8.4,2.8 \mathrm{~Hz}, \mathrm{H}-13\right.$ and $\mathrm{H}-13^{\prime}$ ), $6.60\left(\mathrm{dd}, 2 \mathrm{H}, J=8.4\right.$ and $2.8 \mathrm{~Hz}, \mathrm{H}-11$ and $\left.\mathrm{H}-11^{\prime}\right), 6.28$ (dd, $2 \mathrm{H}, J=8.4$ and $2.8 \mathrm{~Hz}, \mathrm{H}-14$ and $\left.\mathrm{H}-14^{\prime}\right), 7.06$ (dd, 2H, $J=$ 8.5, $2.1 \mathrm{~Hz}, \mathrm{H}-10$ and $\left.\mathrm{H}-10^{\prime}\right) ;{ }^{13} \mathrm{C} \mathrm{NMR}\left(400 \mathrm{MHz}, \mathrm{CDCl}_{3}\right)$ $\delta_{\mathrm{C}} 154.2$ (s, C-12 and C-12'), 152.1 (s, C-6 and C-6'), 143.8 (s, C-18 and C-18'), 139.1 (s, C-7 and C7'), 130.3 (s, C-9 and C-9'), 129.5 (s, C-4a and C-4'a), 128.7 (d, C-14 and C14'), 128.3 (d, C-10 and C- 10'), 124.7 (s, C-8a and C-8'a),
117.5 (d, C-11 and C-11'), 114.0 (d, C-13 and C-13'), 109.2 (d, C-5 and C-5'), 60.1 (q, C-7 and C-7'), 59.6 (d, C-1 and C-1'), 56.0 (q, C-6 and C-6'), 44.6 (t, C-3 and C-3'), 42.3 (q, $2 \times \mathrm{NMe}), 37.9$ (t, $\mathrm{C}-\alpha$ and $\left.\mathrm{C}-\alpha^{\prime}\right), 24.6$ (t, C-4 and C-4'). These data coincide with previous results (Scheinmann et al. 1980).

\section{Antileishmanial screening}

Leishmanicidal activity was assayed on promastigote forms of $L$. infantum PB75 strain, cultured at $28^{\circ} \mathrm{C}$ in Roswell Park Memorial Institute (RPMI) medium supplemented with $10 \%$ fetal calf serum. Parasites in logarithmic growth phase from an initial culture with $1 \times 10^{6}$ promastigotes $/ \mathrm{ml}$ were distributed in 96 -well flat-bottom plates. Each well was filled with $90 \mu \mathrm{l}$ of culture after 2 days of incubation. Extracts and compounds were tested at several concentrations (extracts at 800, 400, and $100 \mu \mathrm{g} / \mathrm{ml}$; compounds at 100,10 , and $1 \mu \mathrm{g} / \mathrm{ml}$ ) for $48 \mathrm{~h}$. Amphotericin $\mathrm{B}$ was used as reference drug and parasite viability was analyzed by modified MTT colorimetric assay (González-Coloma et al. 2002). Briefly, after 48 h, $10 \mu \mathrm{l}$ MTT/PMS were added to each well. Incubate $75 \mathrm{~min}$ to occur the reduction of MTT and $100 \mu 1$ sodium dodecyl sulfate (SDS) were added to dissolve formazan crystals obtained as a result of the reduction of MTT. Once the crystals have dissolved (15-30 $\mathrm{min}$ ), the plate was read on a spectrophotometer at $570 \mathrm{~nm}$. The activity was calculated as $\%$ growth inhibition (\%GI) as follows: $\% \mathrm{GI}=100-\left[\left(A_{\mathrm{p}}-A_{\mathrm{b}}\right) /\left(A_{\mathrm{c}}-A_{\mathrm{b}}\right) \times 100\right], \quad A_{\mathrm{p}}$ being the absorbance of problem wells (treated), $A_{\mathrm{c}}$ the absorbance of control wells (not treated), and $A_{\mathrm{b}}$ the absorbance of blank wells (culture medium and vehicle only). When compounds showed activity, intermediate doses were assayed and $\mathrm{GI}_{50}$ values (concentration that inhibits 50\% the growth of the parasites) were determined from linear regression analysis (STATGRAPHICS Plus, version 5.1). All assays were carried out in triplicate.

Trypanocidal in vitro activity

This activity was assayed on epimastigote forms of $T$. cruzi Y strain, cultured in LIT medium supplemented with $10 \%$ fetal calf serum. Parasites in logarithmic growth phase from an initial culture with $2 \times 10^{6}$ epimastigotes $/ \mathrm{ml}$ were distributed in 96-well flat-bottom plates. Each well was filled with $90 \mu \mathrm{l}$ of culture after 2 days of incubation. Extracts and compounds were tested at several concentrations (extracts at 800,400 , and $100 \mu \mathrm{g} / \mathrm{ml}$; compounds at 100,10 , and $1 \mu \mathrm{g} / \mathrm{ml}$ ) for $72 \mathrm{~h}$. Nifurtimox was used as the reference drug, and parasite viability was analyzed by a modified MTT colorimetric assay method as described 
above (González-Coloma et al. 2002; Muelas Serrano et al. 2000). The activity (\%GI and $\mathrm{GI}_{50}$ ) was calculated as described above for Leishmania. All assays were carried out in triplicate.

\section{Cytotoxicity assays}

Mammalian Chinese hamster ovary (CHO) cells were used for these assays. Cells were grown in RPMI medium supplemented with $10 \%$ L-glutamine, $10 \%$ fetal calf serum, and $1 \%$ penicillin/streptomycin at $37^{\circ} \mathrm{C}$ under humidified atmospheric conditions of $5 \% \mathrm{CO}_{2} / 95 \%$ air. Cells were seeded in 96-well flat-bottom microplates with $100 \mu \mathrm{l}$ medium per well (initial densities of $10^{4}$ cells per well) and incubated under the same conditions. After $24 \mathrm{~h}$, the medium was removed and added fresh medium containing the extracts or compounds. Cells were exposed for $48 \mathrm{~h}$ to several concentrations of the extracts and compounds (extracts at 800, 400, and $100 \mu \mathrm{g} / \mathrm{ml}$; compounds at 100,10 , and $1 \mu \mathrm{g} / \mathrm{ml}$ ). The toxicity of reference drugs (amphotericin B and nifurtimox) was also evaluated. Cell viability was analyzed by the MTT colorimetric assay method (Mossman 1983). After 48 h, $10 \mu \mathrm{l}$ of a solution of $5 \mathrm{mg} / \mathrm{ml}$ MTT in PBS was added to each well. After $4 \mathrm{~h}$, the supernatant was removed, and $100 \mu \mathrm{l}$ DMSO were added to each well. The plate is read on a spectrophotometer at 570 and $620 \mathrm{~nm}$. The activity is expressed as the proportion of viable $\mathrm{CHO}$ cells (percentage of viability) as follows: $\%$ of viability $=\left(A_{\mathrm{p}}-A_{\mathrm{b}}\right) /\left(A_{\mathrm{c}}-A_{\mathrm{b}}\right) \times 100$, where $A_{\mathrm{p}}$ is the absorbance of problem wells (treated), $A_{\mathrm{c}}$ is the absorbance of control wells (not treated), and $A_{\mathrm{b}}$ is the absorbance of blank wells (culture medium and vehicle only). When compounds showed activity, intermediate doses were assayed and $\mathrm{GI}_{50}$ values (concentration that inhibits $50 \%$ the growth of the cells) were determined from linear regression analysis (STATGRAPHICS Plus, version 5.1). All assays were carried out in triplicate.

\section{Results and discussion}

\section{Effects of the plant extracts}

The antileishmanial and antitrypanosomal activity of 34 extracts (hexane, chloroform, and 70\% EtOH) obtained from eight Peruvian plant species is reported in Table 2. We also obtained an alkaloidal extract from the aerial parts of C. tomentosum (bark and leaves). Overall, the hexane and chloroform extracts from Cedrela odorata, the alkaloid extract from $C$. tomentosum and the chloroform extract from $T$. serratifolia proved to be the most active against both parasites. Hexane extracts from Tradescantia zebrina and chloroform extract from $Z$. ulei showed selective activity against $T$. cruzi epimastigotes (at $100 \mu \mathrm{g} / \mathrm{ml}$ ). The chloroform and hydroalcoholic extracts from C. tomentosum, and the chloroform extract from Paullinia clavigera exhibited selective activity against $L$. infantum promastigotes (at $100 \mu \mathrm{g} / \mathrm{ml}$ ). We can conclude that $C$. tomentosum bark and $C$. odorata are the most effective extracts against Leishmania, followed by $C$. tomentosum leaves, $T$. serratifolia, and Aristoloquia pilosa. On the other side, C. odorata, A. pilosa, and alkaloid extract of $C$. tomentosum proved to be most effective against Trypanosoma, followed by T. serratifolia, T. zebrina, and Z. ulei.

Table 3 shows the nonspecific cytotoxicity of the extracts tested at the concentrations showing antiparasitic effects. While most of the extracts studied were cytotoxic, the chloroform extract from $C$. odorata bark, the hydroalcoholic extract from $C$. tomentosum bark, the chloroform extract from $P$. clavigera bark, and the hexane extract from leaves of Brunfelsia grandiflora were not.

T. serratifolia, Z. ulei, and B. grandiflora are used in traditional medicine to treat ulcers and wounds caused by leishmaniasis. These plants are applied topically, using macerated leaves or resin or latex (Kvist et al. 2006; Mejia and Rengifo 2000). Our results confirm the presence of compounds with leishmanicidal activity in these plants. The extracts from the bark of $T$. serratifolia and the extracts from stem and leaf of $B$. grandiflora exhibited similar activity against both parasites. In the case of $B$. grandiflora, the stem and the root are the most commonly used plant parts for the treatment of parasitic diseases (Mejia and Rengifo 2000). However, our results showed that the leaves also exhibit antiparasitic activity. C. odorata and other plants of the Meliaceae family have been used in traditional medicine for the treatments of fevers, a characteristic symptom of malaria. Extracts from this plant and genudin derivatives have been previously assayed against Plasmodium with interesting results (Mackinnon et al. 1997). However, this is the first report on its activity against Leishmania or Trypanosoma. It is interesting to note the strong antiparasitic effects of the alkaloidal extract of $C$. tomentosum. Alkaloid extracts from Menispermaceae exhibited antimalarial activity and in vitro toxicity against the tumoral cell lines KB-3, KB-V1 and P-38878 (Lin et al. 1993). Additionally, we found interesting leishmanicidal activity for $P$. clavigera or A. pilosa extracts.

Identification and effects of mixtures and isolated compounds

Two of the four most active plants against both of the parasites (C. tomentosum and $T$. serratifolia), and a plant with selective action against one of them (Z. ulei) were subjected to bioassay-guided fractionation.

The phytochemical study of the active fractions of the underground tuberous stem of $Z$. ulei resulted in the 
Table 2 In vitro activity of hexane (H), chlorophorm (C), hydroalcoholic (E-w), and alkaloid (A) plant extracts against Leishmania infantum and Trypanosoma cruzi

\begin{tabular}{|c|c|c|c|c|c|c|c|}
\hline \multirow[t]{3}{*}{ Plant species and part } & \multirow[t]{3}{*}{ Extract } & \multicolumn{6}{|c|}{$\%$ Growth inhibition } \\
\hline & & \multicolumn{3}{|l|}{ L. infantum } & \multicolumn{3}{|l|}{ T. cruzi } \\
\hline & & $800 \mu \mathrm{g} / \mathrm{ml}$ & $400 \mu \mathrm{g} / \mathrm{ml}$ & $100 \mu \mathrm{g} / \mathrm{ml}$ & $800 \mu \mathrm{g} / \mathrm{ml}$ & $400 \mu \mathrm{g} / \mathrm{ml}$ & $100 \mu \mathrm{g} / \mathrm{ml}$ \\
\hline \multicolumn{8}{|l|}{ Aristoloquia pilosa } \\
\hline \multirow[t]{3}{*}{ Stem } & $\mathrm{H}$ & $99.1 \pm 0.6$ & $99.0 \pm 0.7$ & $37.8 \pm 9.9$ & $100.0 \pm 0.0$ & $99.0 \pm 0.9$ & $59.1 \pm 7.8$ \\
\hline & $\mathrm{C}$ & $95.6 \pm 0.1$ & $89.8 \pm 0.4$ & $73.3 \pm 2.2$ & $98.2 \pm 0.5$ & $95.4 \pm 0.4$ & $88.4 \pm 1.2$ \\
\hline & E-w & 0.0 & 0.0 & 0.0 & $15.1 \pm 3.6$ & 0.0 & 0.0 \\
\hline \multirow[t]{3}{*}{ Leaf } & $\mathrm{H}$ & $99.9 \pm 0.2$ & $98.5 \pm 0.2$ & $40.8 \pm 5.5$ & $100.0 \pm 0.5$ & $99.0 \pm 0.4$ & $42.4 \pm 1.7$ \\
\hline & $\mathrm{C}$ & $92.2 \pm 0.7$ & $84.1 \pm 0.7$ & $60.3 \pm 1.0$ & $91.0 \pm 0.8$ & $86.0 \pm 0.5$ & $76.5 \pm 1.2$ \\
\hline & E-w & $22.0 \pm 4.0$ & 0.0 & 0.0 & $36.7 \pm 8.2$ & $20.4 \pm 2.9$ & 0.0 \\
\hline \multicolumn{8}{|l|}{ Brunfelsia grandiflora } \\
\hline \multirow[t]{3}{*}{ Stem } & $\mathrm{H}$ & $99.0 \pm 0.6$ & $54.6 \pm 2.7$ & 0.0 & $22.0 \pm 9.0$ & 0.0 & 0.0 \\
\hline & $\mathrm{C}$ & $88.0 \pm 3.2$ & $13.0 \pm 1.6$ & $12.0 \pm 1.2$ & $98.0 \pm 1.3$ & $95.0 \pm 2.3$ & $27.2 \pm 2.0$ \\
\hline & E-w & $77.2 \pm 7.3$ & $8.5 \pm 1.8$ & $3.0 \pm 4.2$ & $72.6 \pm 2.1$ & $46.6 \pm 1.6$ & $4.2 \pm 3.7$ \\
\hline \multirow[t]{3}{*}{ Leaf } & $\mathrm{H}$ & $98.1 \pm 0.1$ & $97.4 \pm 1.3$ & $47.9 \pm 7.1$ & $82.0 \pm 1.0$ & $51.5 \pm 2.1$ & 0.0 \\
\hline & $\mathrm{C}$ & $69.2 \pm 0.9$ & $38.8 \pm 13.8$ & $3.1 \pm 3.2$ & $97.7 \pm 0.6$ & $93.5 \pm 0.2$ & $33.2 \pm 2.7$ \\
\hline & E-w & $42.5 \pm 5.8$ & $8.4 \pm 6.2$ & $5.0 \pm 4.5$ & $46.0 \pm 8.7$ & $42.0 \pm 4.8$ & $16.1 \pm 1.8$ \\
\hline \multicolumn{8}{|l|}{ Cedrela odorata } \\
\hline \multirow[t]{3}{*}{ Bark } & $\mathrm{H}$ & $98.1 \pm 0.3$ & $97.3 \pm 0.6$ & $95.9 \pm 0.5$ & $100.0 \pm 0.4$ & $100.0 \pm 0.2$ & $100.0 \pm 0.5$ \\
\hline & $\mathrm{C}$ & $100.0 \pm 1.8$ & $100.0 \pm 0.2$ & $100.0 \pm 0.1$ & $97.9 \pm 0.4$ & $95.1 \pm 1.1$ & $76.5 \pm 1.2$ \\
\hline & E-w & 0.0 & 0.0 & 0.0 & $72.1 \pm 0.7$ & $50.9 \pm 2.3$ & 0.0 \\
\hline \multicolumn{8}{|l|}{ Chondodendron tomentosum } \\
\hline \multirow[t]{3}{*}{ Bark } & $\mathrm{H}$ & $15.0 \pm 9.9$ & 0.0 & 0.0 & $96.5 \pm 0.9$ & $21.7 \pm 5.6$ & 0.0 \\
\hline & $\mathrm{C}$ & $93.0 \pm 1.0$ & $93.0 \pm 0.4$ & $93.0 \pm 1.0$ & $100.0 \pm 0.5$ & $89.9 \pm 2.2$ & $28.0 \pm 1.2$ \\
\hline & E-w & $100.0 \pm 1.1$ & $97.0 \pm 0.4$ & $91.0 \pm 1.2$ & $42.1 \pm 2.6$ & $24.0 \pm 2.2$ & 0.0 \\
\hline \multirow[t]{3}{*}{ Leaf } & $\mathrm{H}$ & $99.0 \pm 0.1$ & $96.0 \pm 0.7$ & $19.68 \pm 2.9$ & $97.2 \pm 0.2$ & $27.3 \pm 5.8$ & 0.0 \\
\hline & $\mathrm{C}$ & $85.6 \pm 10.6$ & $80.5 \pm 4.8$ & $44.0 \pm 6.9$ & $32.8 \pm 7.7$ & $14.5 \pm 5.9$ & 0.0 \\
\hline & E-w & $89.0 \pm 3.1$ & $87.0 \pm 2.0$ & $84.0 \pm 1.0$ & $27.9 \pm 0.6$ & $4.0 \pm 5.1$ & 0.0 \\
\hline Bark \& leaf & A & $100.0 \pm 4.2$ & $100.0 \pm 2.2$ & $100 \pm 0.0^{\mathrm{a}}$ & $82.9 \pm 4.0$ & $90.9 \pm 0.7$ & $96.5 \pm 0.5^{\mathrm{a}}$ \\
\hline \multicolumn{8}{|l|}{ Paullinia clavigera } \\
\hline \multirow[t]{3}{*}{ Bark } & $\mathrm{H}$ & $93.9 \pm 1.5$ & $92.1 \pm 0.9$ & $20.1 \pm 3.4$ & $56.0 \pm 2.2$ & $47.2 \pm 3.0$ & $5.7 \pm 5.2$ \\
\hline & $\mathrm{C}$ & $100.0 \pm 0.8$ & $100.0 \pm 2.7$ & $74.1 \pm 5.6$ & $100.0 \pm 0.2$ & $89.9 \pm 1.0$ & $38.4 \pm 3.6$ \\
\hline & E-w & 0.0 & 0.0 & 0.0 & 0.0 & 0.0 & 0.0 \\
\hline \multicolumn{8}{|l|}{ Tabebuia serratifolia } \\
\hline \multirow[t]{3}{*}{ Bark } & $\mathrm{H}$ & $100.0 \pm 0.5$ & $99.1 \pm 0.7$ & $37.8 \pm 9.9$ & $100.0 \pm 0.2$ & $99.5 \pm 0.5$ & $24.8 \pm 4.0$ \\
\hline & $\mathrm{C}$ & $100.0 \pm 0.4$ & $98.9 \pm 2.8$ & $90.5 \pm 0.7$ & $98.0 \pm 1.3$ & $96.0 \pm 1.0$ & $94.0 \pm 0.7$ \\
\hline & E-w & $1.5 \pm 3.2$ & 0.0 & 0.0 & $47.6 \pm 1.8$ & $28.5 \pm 3.7$ & $14.3 \pm 1.6$ \\
\hline \multicolumn{8}{|l|}{ Tradescantia zebrina } \\
\hline \multirow[t]{3}{*}{ Aerial part } & $\mathrm{H}$ & $96.4 \pm 1.2$ & $93.5 \pm 0.4$ & $7.8 \pm 1.4$ & $96.0 \pm 1.4$ & $95.0 \pm 1.0$ & $73.5 \pm 3.2$ \\
\hline & $\mathrm{C}$ & $23.8 \pm 3.2$ & $6.3 \pm 2.0$ & $4.1 \pm 2.7$ & $27.0 \pm 11.6$ & 0.0 & 0.0 \\
\hline & E-w & 0.0 & 0.0 & 0.0 & $35.7 \pm 7.1$ & $17.4 \pm 7.4$ & $13.4 \pm 4.4$ \\
\hline \multicolumn{8}{|l|}{ Zamia ulei } \\
\hline Underground tuberous stem & $\mathrm{H}$ & $84.7 \pm 1.0$ & $72.2 \pm 1.3$ & $27.5 \pm 3.5$ & $78.2 \pm 2.0$ & $77.0 \pm 0.6$ & $28.2 \pm 6.2$ \\
\hline & $\mathrm{C}$ & $93.3 \pm 1.2$ & $84.2 \pm 1.3$ & 0.0 & $92.5 \pm 2.3$ & $88.2 \pm 0.2$ & $62.9 \pm 1.0$ \\
\hline & E-w & 0.0 & 0.0 & 0.0 & $26.4 \pm 5.7$ & $10.1 \pm 1.4$ & $7.8 \pm 3.3$ \\
\hline
\end{tabular}

${ }^{\mathrm{a}}$ Concentration assayed: $200 \mu \mathrm{g} / \mathrm{ml}$ 
Table 3 In vitro cytotoxicity of hexane $(\mathrm{H})$, chlorophorm $(\mathrm{C})$, hydroalcoholic (E-w), and alkaloid (A) plant extracts on $\mathrm{CHO}$ cells
The activity is expressed as the proportion of viable $\mathrm{CHO}$ cells (percentage of viability) after $48 \mathrm{~h}$ of contact with the extract. Only the extracts and concentrations active on parasites were assayed on CHO cells

${ }^{\mathrm{a} C o n c e n t r a t i o n}$ assayed: 200 $\mu \mathrm{g} / \mathrm{ml}$

\begin{tabular}{|c|c|c|c|c|}
\hline \multirow[t]{2}{*}{ Plant species and part } & \multirow[t]{2}{*}{ Extract } & \multicolumn{3}{|c|}{$\%$ of viability } \\
\hline & & $800 \mu \mathrm{g} / \mathrm{ml}$ & $400 \mu \mathrm{g} / \mathrm{ml}$ & $100 \mu \mathrm{g} / \mathrm{ml}$ \\
\hline \multicolumn{5}{|l|}{ Aristoloquia pilosa } \\
\hline \multirow[t]{2}{*}{ Stem } & $\mathrm{H}$ & $0.2 \pm 0.2$ & $1.2 \pm 0.2$ & $9.5 \pm 1.6$ \\
\hline & $\mathrm{C}$ & $17.3 \pm 3.1$ & $22.3 \pm 0.5$ & $33.5 \pm 1.6$ \\
\hline \multirow[t]{2}{*}{ Leaf } & $\mathrm{H}$ & $0.5 \pm 0.4$ & $0.2 \pm 0.1$ & - \\
\hline & $\mathrm{C}$ & $1.9 \pm 0.4$ & $5.5 \pm 2.1$ & - \\
\hline \multicolumn{5}{|l|}{ Brunfelsia grandiflora } \\
\hline \multirow[t]{3}{*}{ Stem } & $\mathrm{H}$ & $3.4 \pm 0.8$ & $30.9 \pm 3.0$ & $35.7 \pm 5.7$ \\
\hline & $\mathrm{C}$ & $4.2 \pm 1.7$ & - & - \\
\hline & E-w & $0.4 \pm 0.2$ & - & - \\
\hline Leaf & $\mathrm{H}$ & 0.0 & $58.5 \pm 3.4$ & $49.9 \pm 6.2$ \\
\hline \multicolumn{5}{|l|}{ Cedrela odorata } \\
\hline \multirow[t]{2}{*}{ Bark } & $\mathrm{H}$ & 0.0 & 0.0 & $1.72 \pm 1.7$ \\
\hline & $\mathrm{C}$ & $67.1 \pm 1.6$ & $95.5 \pm 7.0$ & $100.0 \pm 10.5$ \\
\hline \multicolumn{5}{|l|}{ Chondodendron tomentosum } \\
\hline \multirow[t]{3}{*}{ Bark } & $\mathrm{H}$ & $0.7 \pm 0.4$ & $1.8 \pm 1.2$ & - \\
\hline & $\mathrm{C}$ & $1.9 \pm 0.9$ & $1.4 \pm 0.7$ & $2.6 \pm 1.5$ \\
\hline & E-w & $48.6 \pm 17.0$ & $87.9 \pm 13.23$ & $66.0 \pm 11.1$ \\
\hline \multirow[t]{2}{*}{ Leaf } & $\mathrm{C}$ & 0.0 & 0.0 & - \\
\hline & E-w & $12.7 \pm 1.9$ & $4.3 \pm 1.8$ & $14.5 \pm 1.6$ \\
\hline Bark \& leaf & A & $0.5 \pm 0.3$ & $0.2 \pm 0.2$ & $0.0^{\mathrm{a}}$ \\
\hline \multicolumn{5}{|l|}{ Paullinia clavigera } \\
\hline \multirow[t]{2}{*}{ Bark } & $\mathrm{H}$ & $0.9 \pm 0.6$ & $0.2 \pm 0.3$ & - \\
\hline & $\mathrm{C}$ & $1.2 \pm 0.5$ & $7.8 \pm 0.9$ & $72.7 \pm 1.6$ \\
\hline \multicolumn{5}{|l|}{ Tabebuia serratifolia } \\
\hline \multirow[t]{2}{*}{ Bark } & $\mathrm{H}$ & 0.0 & $1.8 \pm 0.9$ & - \\
\hline & $\mathrm{C}$ & 0.0 & 0.0 & - \\
\hline \multicolumn{5}{|l|}{ Tradescantia zebrina } \\
\hline Aerial part & $\mathrm{H}$ & 0.0 & $27.9 \pm 2.5$ & - \\
\hline \multicolumn{5}{|l|}{ Zamia ulei } \\
\hline \multirow[t]{2}{*}{ Underground tuberous stem } & $\mathrm{H}$ & $0.1 \pm 0.1$ & $40.0 \pm 1.5$ & - \\
\hline & $\mathrm{C}$ & $4.0 \pm 3.3$ & $1.0 \pm 0.6$ & - \\
\hline
\end{tabular}

isolation of cycasin (1) (Fig. 1). Cycasin (1) has previously been isolated from other species such as Cycas revoluta (Nishida et al. 1955, 1956), Bowenia spectabilis, Stangeria eriopus, Ceratozamia mexicana, Lepidozamia hopei, Encephalartos villosus, Macrozamia miquelii, and Zamia fischeri (Yagi 2004).

Mixtures 1 and 2 were isolated from T. serratifolia, and they were identified using GC-MS. Their composition is shown in Table 4. Mixture 1 is composed of saturated alkanes and the isoflavonoid rotenalone which is the major component $(15.1 \%)$, followed by triacontane $(6.2 \%)$, hentriacontane $(6.0 \%)$, and an unknown compound of $[\mathrm{M}]^{+} 396(6.0 \%)$. Rotenalone has been reported as cytotoxic against the A 2,780 human ovarian cancer cell line (Cao et al. 2004). The major components of mixture 2 were two unidentified compounds of $[\mathrm{M}]^{+} 422(6.7 \%)$ and
$[\mathrm{M}]^{+} 396(6.9 \%)$. Among the compounds present in mixture 2, eicosane, octacosane, and octadecane are present in essential oils and extracts of various plants, and their activity on various bacteria, fungi, and viruses have been reported (Zai-Chang et al. 2005; Kuiate et al. 2006; Karabay et al. 2007; Mazutti et al. 2008).

Naphthoquinones $\mathbf{2}$ and $\mathbf{3}$ were also isolated from $T$. serratifolia. They were identified using spectroscopic techniques (MS, IR, UV) and mono and two-dimensional ${ }^{1} \mathrm{H}$ and ${ }^{13} \mathrm{C}$ NMR (COSY, HSQC, NOESY) experiments (Fig. 1). Both were previously isolated from Tabebuia cassinoides and T. ochracea (Zani et al. 1991).

The bisbenzylisoquinoline alkaloids (BBIQs) chondrocurine (4), $\left(S, S^{\prime}\right)$-12-O-methyl(+)-curine (5), and cycleanine (6) were isolated from $C$. tomentosum. They were identified by spectroscopic techniques (MS, IR, UV) and ${ }^{1} \mathrm{H}$ NMR 


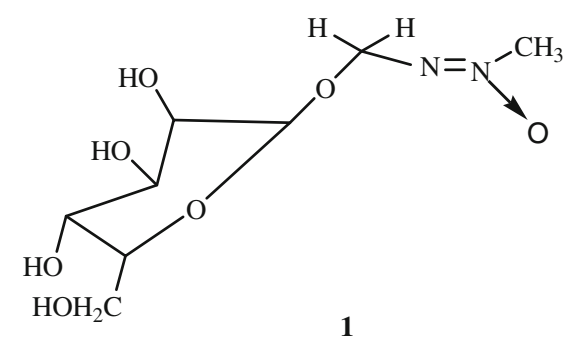<smiles>[R]C(C)c1cc2c(o1)C(=O)c1ccccc1C2=O</smiles>

$$
\begin{aligned}
& \text { 2; } \mathrm{R}=\mathrm{O} \\
& \mathbf{3} ; \mathrm{R}=-\mathrm{OH}
\end{aligned}
$$

Fig. 1 Chemical structures of cycasin (1) and naphthoquinones 2 and $\mathbf{3}$

and ${ }^{13} \mathrm{C}$ mono and two-dimensional (COSY, HSQC, NOESY) experiments (Fig. 2).

Chondrocurine (4) was first isolated from C. tomentosum (Everette et al. 1970) and also found in other species of the family. Compound 5 was first identified as (++)-4"-Omethylcurine from Cissampelos pareira (Haynes et al.
1966). Cycleanine (6) is present in a wide range of Menispermaceae and also in other families such as Annonaceae (Leboeuf et al. 1982).

Table 5 shows the antiparasitic and cytotoxic effects of the mixtures and pure compounds. Mixture 1 exhibited moderate antileishmanial effects while mixture 2 showed important activity against both parasites with higher potency than nifurtimox and cytotoxicity values similar to those of the reference drugs. Both naphthoquinones proved to be quite active against both parasites (especially 3 ) with $\mathrm{GI}_{50}$ values for $T$. cruzi lower than those of nifurtimox and similar to amphotericin B for L. infantum. Although these compounds are more toxic to $\mathrm{CHO}$ mammalian cells than the reference drugs, it should be noted that compound $\mathbf{3}$ is $300 \times$ more active on epimastigote forms of $T$. cruzi than nifurtimox.

Alkaloid $\mathbf{6}$ exhibited no significant activity, but $\mathbf{4}$ and $\mathbf{5}$ were active against both parasites (with lower potency than the reference drugs). These compounds exhibited strong activity against Leishmania but were less toxic to mammalian $\mathrm{CHO}$ cells than the reference drugs. This variation in activity may be due to the fact that $\mathbf{6}$ is composed of two coclaurinetype isoquinoline units linked by two $\mathrm{C} 8-\mathrm{C} 12^{\prime}$ and $\mathrm{C} 8{ }^{\prime}-\mathrm{C} 12$ head-tail ether bonds, while in $\mathbf{4}$ and $\mathbf{5}$, the units are linked by $\mathrm{C} 8-\mathrm{C} 12^{\prime}$ and $\mathrm{C} 11-\mathrm{C} 7^{\prime}$ head-tail bonds. Previous studies with compounds such as isotetrandrine, pheanthine, cepha-
Table 4 Chemical composition

\begin{tabular}{|c|c|c|c|}
\hline & Compound & Retention time & Relative abundance $(\%)$ \\
\hline \multirow[t]{14}{*}{ Mixture 1} & Tricosane & 43.09 & 1.5 \\
\hline & Tetracosane & 45.22 & 3.1 \\
\hline & Pentacosane & 47.25 & 2.7 \\
\hline & $222[\mathrm{M}]^{+}$ & 47.43 & 1.4 \\
\hline & Hexacosane & 49.24 & 3.9 \\
\hline & Heptacosane & 51.13 & 3.7 \\
\hline & Octacosane & 52.97 & 3.0 \\
\hline & Nonacosane & 54.72 & 2.5 \\
\hline & Triacontane & 56.49 & 6.2 \\
\hline & $394[\mathrm{M}]^{+}$ & 56.88 & 1.0 \\
\hline & Hentriacontane & 57.86 & 6.0 \\
\hline & $396[\mathrm{M}]^{+}$ & 57.86 & 6.0 \\
\hline & $408[\mathrm{M}]^{+}$ & 62.67 & 2.7 \\
\hline & Rotenalone & 64.06 & 15.1 \\
\hline$\%$ Identified & & & 58.8 \\
\hline \multirow[t]{6}{*}{ Mixture 2} & $422[\mathrm{M}]^{+}$ & 45.28 & 6.7 \\
\hline & Eicosane & 49.27 & 1.5 \\
\hline & Docosane & 51.15 & 1.7 \\
\hline & Octadecane & 52.96 & 1.4 \\
\hline & $394[\mathrm{M}]^{+}$ & 57.50 & 5.4 \\
\hline & $396[\mathrm{M}]^{+}$ & 57.84 & 6.9 \\
\hline$\%$ Identified & & & 23.6 \\
\hline
\end{tabular}
of mixtures $1-2$ 


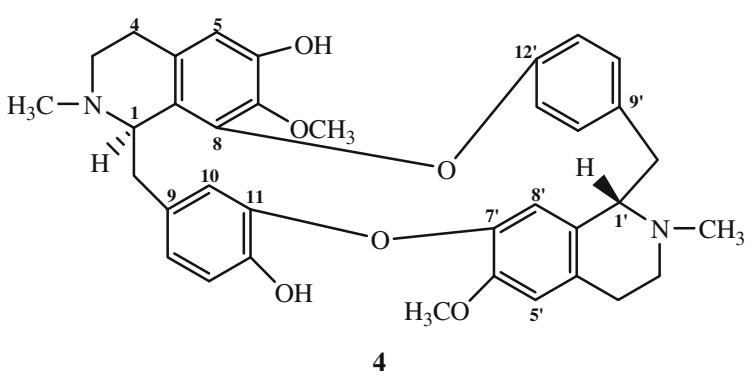<smiles>COc1ccc(Cc2ccc(C[C@H]3Oc4cc(ccc4OC)CCN(C)[C@H]3C)cc2)cc1O</smiles>

5

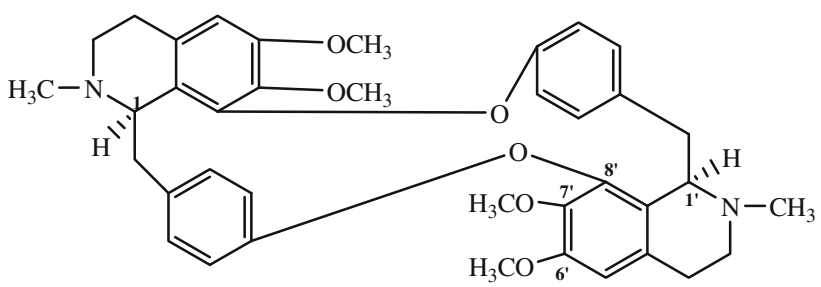

6

Fig. 2 Chemical structures of chondrocurine (4), $\left(S, S^{\prime}\right)$-12-O-methyl $(+)$-curine (5) and cycleanine (6)

ranthine and cycleanine highlight the important role played by stereochemistry in their activity (Thornber 1970).

In our study, cycasin (1) was not active. This compound is a toxic azoxyglycoside whose main metabolite, methylazoxymethanol (MAM), is responsible for insect toxicity and genetic alterations in different systems (bacteria, yeasts, plants, mammalian cells, etc.; Schneider et al. 2002; Yagi 2004). Therefore, the lack of activity of 1 may be due to its low bioavailability to the parasites and/or cells due to its high polarity, resulting in low amounts of released MAM (responsible for the toxicity).

The naphthoquinones, lapachol, and lapachone, found in the genus Tabebuia, proved active against Schistosoma mansoni and T. cruzi (Do Campo et al. 1977, 1978). Lapachol showed significant leishmanicidal activity in vitro, high activity against $T$. cruzi and also interferes with oxygen metabolism of tumor cells by blocking celular respiration and the generation of oxygen free radicals (Hussain et al. 2007). Other naphthoquinones act by inducing oxidative stress, reducing the consumption of oxygen in the respiratory chain, and inhibiting electron transport (Colman de Saizarbitoria et al. 1997). It has also been reported that the activity of naphthoquinones against sensitive and resistant strains of Plasmodium falciparum to chloroquine may be due to the presence of a methyl group which increases its lipophilicity promoting drug accumulation in the mitochondria of the parasite (Weiss et al. 2000). Naphthoquinones 2 and $\mathbf{3}$ exhibited significant activity against tumor cells KB (Rao and Kingston 1982; Zani et al. 1991). In addition, naphthoquinone $\mathbf{3}$ showed significant activity against Trypanosoma brucei brucei, Trypanosoma brucei rhodesiense, $P$. falciparum, and P. berghei (Weiss et al. 2000; Fournet and Muñoz 2002) and against a wide range of microorganisms (Kuete et al. 2007). Naphthoquinone 3 could have an antiparasitic mode of action similar to that described for other naphtoquinones, while the presence of a hydroxyethyl group in its side chain could be responsible for an increase in activity compared to $\mathbf{2}$. This is the first time that the activity of these compounds against $L$. infantum and $T$. cruzi has been described, although their activity has been reported for other species of Trypanosoma.

BBIQ alkaloids proved to be active against $T$. cruzi and $P$. falciparum, and some of them enhance the effect of different antimalarial drugs and revert parasite resistance (Lin et al. 1993). S, $S^{\prime}$-12-O-methyl-curine (5) is present in a root extract of Cissampelos mucronata with activity against
Table 5 In vitro activity on Leishmania infantum, Trypanosoma cruzi, and $\mathrm{CHO}$ cells of mixtures $1-2$ and compounds 1-6
Results are expressed in $\mathrm{GI}_{50}$ $(\mu \mathrm{g} / \mathrm{ml})$. In brackets, confidence limits 95\%

\begin{tabular}{llll}
\hline Compound & L. infantum & T. cruzi & CHO cells \\
\hline Mixture 1 & $35.07(18.99-64.76)$ & $>100$ & $67.54(48.11-94.82)$ \\
Mixture 2 & $2.49(2.22-2.80)$ & $1.57(0.55-4.49)$ & $11.02(8.92-13.62)$ \\
$\mathbf{1}$ & $>100$ & $>100$ & $59.54(37.59-94.31)$ \\
$\mathbf{2}$ & $2.15(1.97-2.35)$ & $2.36(2.03-2.75)$ & $5.39(4.16-6.97)$ \\
$\mathbf{3}$ & $0.19(0.03-1.09)$ & $0.01(0.001-0.04)$ & $2.72(1.12-6.61)$ \\
$\mathbf{4}$ & $0.85(0.55-1.29)$ & $21.69(13.50-33.19)$ & $45.48(37.81-54.69)$ \\
$\mathbf{5}$ & $0.76(0.46-1.25)$ & $22.83(15.74-33.10)$ & $41.69(38.15-45.57)$ \\
$\mathbf{6}$ & $52.96(29.76-94.21)$ & $>100$ & $51.41(27.62-57.69)$ \\
Nifurtimox & & $3.39(1.40-8.19)$ & $13.91(9.09-21.30)$ \\
Amphotericin B & $0.04(0.01-0.12)$ & & $10.25(5.36-19.61)$
\end{tabular}


chloroquine-sensitive and chloroquine-resistant $P$. falciparun strains (W2 and D6) and showed moderate cytotoxicity against KB cells (Tshibangu et al. 2003). Cycleanine (6) showed activity against $P$. falciparum (chloroquinesensitive clone D6; Angerhofer et al. 1999), in vitro antibacterial and strong fungicidal activity (LohomboEkomba et al. 2004), and in vitro activity against Leishmania brasiliensis, Leishmania amazonensis, and Leishmania donovani, but not to T. cruzi (Osorio et al. 2006). Furthermore, 6 showed strong activity in mice infected with $\mathrm{CL}$ and $\mathrm{Y}$ strains of $T$. cruzi when administered together with other alkaloids such as curine, isotetrandine, limacine, and pheanthine (Fournet et al. 1997). Previous studies have reported that BBIQ alkaloids act on the trypanothione reductase (a pathogen-specific enzyme which is one of the main targets in the search for new drugs against $T$. cruzi) similarly to other inhibitors of this enzyme (nitrofurans and naphthoquinones), which have a positive charge attached to a hydrophobic group. The enzyme is inhibited when binding occurs, interfering with catalysis of trypanothione disulfide reduction (the compound responsible for oxygen exchange), the level of oxygen in the parasite is reduced, and death occurs (Fournet et al. 1998).

\section{Conclusions}

The results confirm the presence of leishmanicidal activity for plants used for the treatment of ulcers ( $T$. serratifolia, Z. ulei, or B. grandiflora) and other uses $(C$. tomentosum, C. odorata, P. clavigera, T. zebrine, or A. pilosa). Some extracts also exhibited interesting trypanocidal activity. We also isolated the active compounds responsible for the activity of $C$. tomentosum alkaloidal extract and T. serratifolia chlorophorm extract. However, the major compounds isolated from the active fractions of $Z$. ule $i$ were not active. One cause may be that the active principle is present in a low proportion in the extract and has not been isolated, or synergistic effects is existent in the extract. To further check this, studies with combinations of different compounds isolated from the extract must be done.

Acknowledgments This work was supported by grant CTQ200914629-C02-01 (Spain) and a collaborative research project CSICCONCYTEC (Perú). We also thank S. Carlin for language revision.

\section{References}

Angerhofer C, Guinaudeau H, Wongpanich V, Pezzuto JM, Cordell A (1999) Antiplasmodial and cytotoxic activity of natural bisbenzylisoquinoline alkaloids. J Nat Prod 62:59-66
Cao S, Schilling JK, Miller JS, Andriantsiferana R, Rasamison VE, Kingston DG (2004) Cytotoxic compounds from Mundulea chapelieri from the Madagascar Rainforest. J Nat Prod 67:454456

Colman de Saizarbitoria T, Anderson JE, Alfonso D, MacLaughlin JL (1997) Bioactive furonaphtoquinones from Tabebuia barbata, Bignoniaceae. Acta Cient Venez 48:42-46

Correa DS, Tempone AG, Reimao JQ, Taniwaki NN, Romoff P, Fávero OA, Sartorelli P, Mecchi MC, Lago JHG (2011) Antileishmanial and anti-trypanosomal potential of polygodial isolated from stem barks of Drimys brasiliensis. Parasitol Res 109:231-236

Croft SL, Barrett MP, Urbina JA (2005) Chemotherapy of trypanosomiases and leishmaniasis. Trends Parasitol 21:508-512

Do Campo R, Lopes JN, Cruz FS, De Soua W (1977) Trypanosoma cruzi: ultrastructural and metabolic alterations of epimastigotes by $\beta$-lapachone. Exp Parasitol 42:142-149

Do Campo R, Cruz FS, Boveris A, Muniz RP, Esquibel DM (1978) Lipid peroxidation and the generation of free radicals, superoxide anion, and hydrogen peroxide in beta-lapachone-treated Trypanosoma cruzi epimastigotes. Arch Biochem Biophys 186:292297

Everette AJ, Lowe LA, Wilkinson S (1970) Revision of the structure of (+)-tubocurarine chloride and (+)-chondrocurine. J Chem Soc D 1970:1020-1021

Estevez Y, Castillo D, Pisango MT, Arevalo J, Rojas R, Alban J, Deharo E, Bourdy G, Sauvain M (2007) Evaluation of the leishmanicidal activity of plants used by Peruvian Chayahuita ethnic group. J Ethnopharmacol 114:254-259

Fournet A, Muñoz V (2002) Natural products as trypanocidal, antileishmanial and antimalarial drugs. Curr Top Med Chem 2:1215-1237

Fournet A, Ferreira ME, Rojas de Arias A, Schinini A, Nakayama H, Torres S, Sanabria R, Guinaudeau H, Bruneton J (1997) The effects of bisbenzylisoquinoline alkaloids in $T$. cruzi infections in mice. Int J Antimicrob Agents 8:163-170

Fournet A, Inchaustti A, Yaluff G, Rojas de Arias A, Guinaudeau H, Bruneton J, Breidenbach MA, Karplus PA, Faerman CH (1998) Trypanocidal bisbenzylisoquinoline alkaloids are inhibitors of trypanothione reductasa. J Enzyme Inhib 13:1-9

Gascon J, Bern C, Pinazo MJ (2010) Chagas disease in Spain, the United States and other non-endemic countries. Acta Trop 115:22-27

González-Coloma A, Guadaño A, de Inés C, Martínez-Díaz R, Cortés D (2002) Selective action of acetogenin mitochondrial Complex I inhibitors. Z Naturforsch 57C:1028-1034

Ghosh S, Debnath S, Hazra S, Hartung A, Thomale K, Schutheis M, Kapkova P, Schurigt U, Moll H, Holzgrabe U, Hazra B (2011) Valeriana wallichii root extracts and fractions with activity against Leishmania spp. Parasitol Res 108:861-871

Haynes LJ, Herbert EJ, Plimmer JR (1966) (++)-4"-O-Methylcurine from Cissampelos pareira. J Chem Soc C 1966:615-617

Hussain H, Krohn K, Uddin Ahmad V, Abbas Miana G, Robert Green I (2007) Lapachol: an overview. ARKIVOC 2:145-171

Karabay NU, Sukatar A, Ozdemir G, Horzum Z (2007) Antimicrobial activity of volatile components and various extracts of the red alga Jania rubens. Phytother Res 21:153-156

Kuete V, Eyong KO, Folefoc GN, Beng VP, Hussain H, Krohn K, Nkengfack AE (2007) Antimicrobial activity of the methanolic extract and the chemical constituents isolated from Newbouilda laevis. Die Pharmazie 62:552-556

Kuiate JR, Bessiere JM, Zollo PHA, Kuate SP (2006) Chemical composition and antidermatophytic properties of volatile fractions of hexanic extract from leaves of Cupressus lusitanica Mill. from Cameroon. J Ethnopharmacol 103:160 165 
Kvist LP, Christensen SB, Rasmussen HB, Mejía K, González A (2006) Identification and evaluation of Peruvian plants used to treat malaria and leishmaniasis. J Ethnopharmacol 106:390-402

Leboeuf M, Cavé A, Bhaunik PK, Mukherjee B, Mukherjee R (1982) The phytochemistry of the Annonaceae. Phytochemistry 21:2783-2813

Lin LZ, Shied HL, Angerhofer CK, Pezzuto JM, Cordell GA (1993) Citotoxic and antimalarial bisbenzylisoquinoline alkaloids from Cyclea barbata. J Nat Prod 56:22-29

Lohombo-Ekomba ML, Okusa PN, Penge O, Kabongo C, Iqbal M, Kasende OE (2004) Antibacterial, antifungal, antiplasmodial and cytotoxic activities of Albertisia villosa. J Ethnopharmacol 93:331-335

Mackinnon S, Durst T, Arnason JT (1997) Antimalarial activity of tropical Meliaceae extracts and gedunin derivatives. J Nat Prod 60:336-341

Mazutti M, Mossi AJ, Cansian RL, Corazza ML, Dariva C, Oliveira V (2008) Chemical profile and antimicrobial activity of Boldo (Peumus boldus Molina). Extracts obtained by compressed carbon dioxide extraction. Braz J Chem Eng 25:427-434

Mejia K, Rengifo E (2000) Plantas medicinales de uso popular en la Amazonía Peruana. Instituto de Investigación de la Amazonía Peruana - Gobierno Regional de Loreto - Agencia Española de Cooperación Internacional, Lima

Mossman T (1983) Rapid colorimetric assay for cellular growth and survival: Application to proliferation and cytotoxicity assays. J Immunol Methods 65:55-63

Muelas Serrano S, Nogal JJ, Martínez Díaz RA, Escario JA, Martínez Fernández AR, Gómez Barrio A (2000) In vitro screening of American plant extracts on Trypanosoma cruzi and Trichomonas vaginalis. J Ethnopharmacol 71:101-107

Muñoz J, Portús M, Corachan M, Fumadó V, Gascona J (2007) Congenital Trypanosoma cruzi infection in a non-endemic area. Trans R Soc Trop Med Hyg 101:1161-1162

Murray HW, Berman JD, Davies CR, Saravia NG (2005) Advances in leishmaniasis. Lancet 366:1561-1577

Nishida K, Kobayashi A, Nagahama T (1955) Studies on cycasin, a new toxic glycoside of Cycas revoluta Thunb. Part I. Isolation and structure of cycasin. Bull Agric Chem Soc Japan 19:77-83

Nishida K, Kobayashi A, Nagahama T (1956) Studies on cycasin, a new toxic glycoside of Cycas revoluta Thunb. Part III. Isolatión of cycasin from the stem of Japanese cycad. Seikagaku 28:70-74

Osorio J, Montoya G, Arango G (2006) Productos naturales alcaloidales con actividad antiprotozoaria. Vitae 13:61-84

Passero LFD, Bonfim-Melo A, Corbett CEP, Laurenti MD, Toyama MH, de Toyama DO, Romoff P, Fávero OA, dos Grecco SS,
Zalewsky CA, Lago JHG (2011) Anti-leishmanial effects of purified compounds from aerial parts of Baccharis uncinella $\mathrm{C}$. (Asteraceae). Parasitol Res 108:529-536

Perez D, Iannacone J (2006) Effectiveness of botanical extracts from ten plants on mortality and larval repellency of Rhynchophorus palmarum L., an insect pest of the Peach palm Bactris gasipaes Kunth in Amazonian Peru. Agric Tec 66:21-30

Rao MM, Kingston DGI (1982) Plant anticancer agents. XII. Isolation and structure elucidation of new cytotoxic quinones from Tabebuia cassinoides. J Nat Prod 45:600-604

Reina M, González-Coloma A, Gutiérrez C, Cabrera R, Rodríguez ML, Villarroel L, Fajardo V (2001) Defensive chemistry of Senecio miser Hook. J Nat Prod 64:6-11

Rojas R, Bustamante B, Bauer J, Fernández I, Albán J, Lock O (2003) Antimicrobial activity of selected Peruvian medicinal plants. J Ethnopharmacol 88:199-204

Sánchez-Cañete MP, Carvalho L, Pérez-Victoria FJ, Gamarro F, Castanys S (2009) Low plasma membrane expression of the miltefosine transport complex renders Leishmania braziliensis refractory to the drug. Antimicrob Agents Chemother 53:13051313

Schneider D, Wink M, Sporer F (2002) Cycads: their evolution, toxins, herbivores and insect pollinators. Naturwissenschaften 89:281-294

Scheinmann F, Scriven EFV, Ogbeibe ON (1980) Cycleanine from Synclisia scabrida: conformational information from the ${ }^{1} \mathrm{H}$ NMR spectrum at $300 \mathrm{MHz}$. Phytochemistry 19:1837-1840

Sra KK, Sracic J, Tyring SK (2004) Treatment of protozoan infections. Dermatol Ther 17:513-516

Thornber CW (1970) Alkaloids of the Menispermaceae. Phytochemistry 9:157-187

Tshibangu JN, Wright AD, Köning GM (2003) HPLC isolation of the antiplasmodially active bisbenzylisoquinoline alkaloids present in roots of Cissampelos mucronata. Phytochem Anal $14: 13-22$

Weiss CR, Moideen SVK, Croft SL, Houghton PJ (2000) Activity of extracts and isolated naphthoquinones from Kigelia pinnata against Plasmodium falciparum. J Nat Prod 63:1306-1309

Yagi F (2004) Azoxyglycoside content and $\beta$-glycosidase activities in leaves of various cycads. Phytochemistry 65:3243-3247

Zai-Chang Y, Bo-Chu W, Xio-Sheng Y, Qiang W (2005) Chemical composition of the volatile oil from Cynanchum stauntonii and its activities of anti-influenza virus. Colloid Surf B Biointerfaces 43:198-202

Zani CL, De Oliveira AB, De Oliveira GG (1991) Furonaphthoquinones from Tabebuia ochracea. Phytochemistry 30:2379-2381 